\title{
HOP (Humulus lupulus L.) BREEDING AIMED AT HIGH CONTENTS OF DESMETHYLXANTHOHUMOL (DMX)
}

\author{
VLADIMÍR NESVADBA, KAREL KROFTA, ZDĚNKA POLONČÍKOVÁ
}

Hop Research Institute Co., Ltd., Žatec

\begin{abstract}
NESVADBA, V. - KROFTA, K. - POLONČÍKOVÁ, Z.: Hop (Humulus lupulus L.) breeding aimed at high contents of desmethylxanthohumol (DMX). Agriculture (Polnohospodárstvo), vol. 57, 2011, no. 3, pp. 105-109.
\end{abstract}

Three female plants (cultivars Agnus, Columbus and Admiral) and two male genotypes (99/14 and 00/6) were chosen for diallel breeding. The highest content of desmethylxanthohumol (DMX) was determined in the progenies of "Agnus $\mathrm{x}$ male $99 / 14$ and $00 / 6$ ", resp. However, the differences between the progenies were not statistically significant. Within combination breeding the highest content of DMX was found in genotypes originating from cultivar Vital. These progenies show higher contents of DMX than the other ones with $99 \%$ probability. In the second part of the breeding process aimed at high content of DMX we tested the hop gene pool as well as contemporary breeding material. In currently cultivated bitter hop cultivars the contents of DMX are low from 0.14 to $0.18 \%$ (Agnus, Magnum, Sládek, Dunav, Pioneer, etc.). New genotype with very high content of $\operatorname{DMX}(0.37$, resp. $0.27 \%)$. In 2008 the first Czech hop cultivar (Vital) for pharmaceutical utilization was released. This variety shows high content of pharmaceutically needed compound, DMX $(0.3-0.4 \% \mathrm{w} / \mathrm{w})$. In comparison with other bitter cultivars of hops this content is $2-3 \times$ higher.

Key words: hops, Humulus lupulus L., desmethylxanthohumol, hop breeding, genetic resources, new breeding material.

Hop breeding has a long tradition in Czech Republic. The first clones of Saaz semi-early red-bine hops were obtained as early as in the $19^{\text {th }}$ century by dr. Sems. Since the beginning of the $20^{\text {th }}$ century a lot of Saaz aroma hops have been bred. New cultivars of hybrid type have begun to be grown since 1994. We managed to register six of them till 2007. Many breeding objectives are preferred at present. The main aim is to obtain new genotypes which will show the resistance to biotic and abiotic factors, needed contents and ratio of hop resins according to the individual types of hops, high and stable yield as well as good agro-technical parameters (Nesvadba \& Krofta 2003). Since 2006 our breeding process has been aimed at pharmaceutical utilization representing high contents of xanthohumol and desmethylxanthohumol (DMX). The highest contents of xanthohumol (at the level of $1.0 \%$ ) are known for a German cultivar Taurus, English Admiral and
Czech Agnus (Krofta \& Nesvadba 2008). The highest contents of DMX (0.14-0.18\%) were determined at Magnum, Sládek, Dunav, Pioneer, etc. (Nesvadba 2007).

The increasing interest in pharmaceutically important compounds found in hop cones has been typical for recent pharmaceutical industry. Prenylflavonoids are known to have antioxidant, anti-inflammatory, anti-virus and anti-carcinogenic effects. Xanthohumol and dehydrocycloxanthohumol are efficient at activation of chinoreductase. This enzyme protects cells against toxic xenobiotics by reducing chinons and hydrochinons, which are more easily degradable in bodies of mammals (Miranda et al. 2000). DMX is another very important compound of hop cones. It is known to isomerise to 8-prenylnaringenin, which inhibits cytochrome P450 enzymes that are typical for activation of various carcinogens. Bone resorption is also inhibited

Ing. Vladimír Nesvadba, PhD., Hop Research Institute, Co., Ltd., 43846 Žatec, Kadaňská 2525, Czech Republic

E-mail:v.nesvadba@telecom.cz 
by some hop ingredients, mainly by xanthohumol and humulone (Tobe et al. 1997). These compounds are considered to be the perspective therapeutics against osteoporosis. Antioxidant characteristics of prenylflavonoids were discovered during the inhibition of "low density" lipoproteins oxidation, which decreases the risk of cardiovascular diseases (Miranda et al. 2000).

The objective of this work was to obtain suitable parental components, which will be able to transfer high content of DMX to their progenies. New genotypes with high DMX should be developed from them. These will be further tested for practical utilization.

\section{MATERIAL AND METHODS}

For test crossing we used mother plants of Agnus (Czech cultivar), Columbus (US cultivar) and Admiral (UK cultivar). For combination crossing we used mother plants of Agnus and Vital (both Czech cultivars), Taurus (German cultivar) and English cultivars First Gold, Admiral and Pioneer, having their origin in the unique collection of genetic resources (Ministry of Agriculture 33083/03-300 6.2.1). Breeding materials BM 03, BM 14 a BM 28 were tested as well. Male plants were selected from the collection of male genotypes. They were obtained by selection from progenies aimed at high contents of hop resins. The progenies from individual crossings were obtained according to the hop breeding methodology issued by Hop Research Institute, Co., Ltd. in Žatec. The selected plants were planted into a hop nursery and genotypes within progenies were assessed. On the base of the evaluations a set of female tested genotypes was selected from each progeny. Average sample of hop cones was obtained from each tested genotype. The cones were dried under the constant temperature of $55^{\circ} \mathrm{C}$ for eight hours. Chemical analyses for determination of the content and ratio of hop resins as well as DMX and xanthohumol contents in hop cones were quantified by HPLC method (RBC 7.7). The following basic statistical parameters were chosen for the final assessment: average, variability, standard deviation and hundredfold of variation coefficient. The results were processed with the help of statistical program STATISTICA - StatSoft. The data presented were obtained during the research made in the period of 2007-2009. The assessments within seven hop gardens were carried out to determine the influence of a locality on DMX contents in 2007-2009.

\section{RESULTS AND DISCUSSION}

In 2006 the diallel crosses were carried out with the aim to obtain knowledge on parental components and their influence on DMX content in the progenies. Three high-alpha females (cultivars: Agnus, Columbus, Admiral) and two males (99/14 and 00/6 - derived from crosses of parents with high DMX contents) were selected for this purpose. Cultivars Agnus, Columbus and Admiral have high contents of hop resins (De Keukeleire et al. 2003). It resulted from the analyses where Agnus had higher content of DMX than Columbus or Admiral. Average contents of DMX within the individual progenies were shown in Table 1 . They were virtually the same, in the range of $0.10-0.13 \%$. The progenies derived from Agnus only showed higher average values in DMX content $(0.18 \%)$ than the other

$\mathrm{T}$ a

Average contents of DMX in the progenies within the tested crossing

\begin{tabular}{|ll|c|c|}
\hline Female & Male & $\begin{array}{c}99 / 14 \\
(0.07 \% \mathrm{DMX})\end{array}$ & $\begin{array}{c}00 / 6 \\
(0.08 \% \mathrm{DMX})\end{array}$ \\
\hline Agnus & $(0.18 \% \mathrm{DMX})$ & $0.13 \%$ & $0.18 \%$ \\
Columbus & $(0.09 \% \mathrm{DMX})$ & $0.12 \%$ & $0.10 \%$ \\
Admiral & $(0.07 \% \mathrm{DMX})$ & $0.13 \%$ & $0.11 \%$ \\
\hline
\end{tabular}


progenies. Nevertheless, this difference was not statistically significant.

Without combinational crossings carried out in the period since 2007 till 2009 we tested 17 progenies in total. Average contents of DMX as well as the variability according to the origins of the progenies were summarized in Table 2. The progeny H39/07 showed at the level of $99 \%$ probability conclusively higher contents of DMX than the other ones. We found seventeen genotypes with DMX contents over $0.25 \%$. It was obvious from the results that the highest DMX contents showed the progenies having their origin in Czech cultivars Vital and Agnus. On the contrary, it was evident that the cultivars Taurus and First Gold would not be suitable for breeding purposes aimed at high DMX contents. Also, the male genotypes 07/12 were not suitable because their progenies had the lowest DMX contents as well. Nevertheless, the results obtained were only of limited importance as the samples were selected on the basis of visual evaluation (lupuline contents). In spite of this they showed, which parental components would be necessary to use in the following research work. At the same time, we also gained new knowledge on male plants that could be used for further breeding purposes aimed at high contents of DMX.

In the second part of our breeding program aimed at high DMX content we tested unfinished breeding material within nurseries. DMX contents in the world hop cultivars were in the range of $0.15-0.18 \%$ (Table $3)$. We succeeded in obtaining one genotype, BM 14 with extremely high content of DMX $-0.46 \%$. Some other genotypes showed also high contents of DMX (BM $28=0.37 \%$; BM $03=0.27 \%$ ). It will be necessary to test these genotypes in field conditions. We managed to find a new genotype (no. 4715) with high DMX content during the assessment of breeding material as well. This genotype was in registration trials because of its high alpha acids content. Unfortunately, the yield was rather lower and therefore we considered it for rejection from further registration trials being non-perspective for hop breeding. Nevertheless, it may be more perspective for pharmacy than for brewing in-

$\mathrm{T}$ a b 1 e 2

Average content and variability of DMX in progenies within the combination crossing

\begin{tabular}{|c|rcc|c|c|c|}
\hline Progeny & Female & $\times$ & Male & $\begin{array}{c}\text { Average } \\
{[\% \text { w/w }]}\end{array}$ & Standard deviation & $\begin{array}{c}\text { Variation } \\
\text { coefficient }\end{array}$ \\
\hline H39/07 & Vital & $\times$ & OP & 0.206 & 0.032 & 0.161 \\
H16/08 & Vital & $\times$ & OP & 0.195 & 0.062 & 0.321 \\
H4/07 & Agnus & $\times$ & $02 / 1$ & 0.161 & 0.045 & 0.278 \\
H15/07 & Agnus & $\times$ & $05 / 10$ & 0.150 & 0.027 & 0.178 \\
H8/08 & Admiral & $\times$ & $86 / 4$ & 0.140 & 0.052 & 0.369 \\
H13/07 & Admiral & $\times$ & $98 / 10$ & 0.134 & 0.056 & 0.419 \\
H5/09 & 5157 & $\times$ & $99 / 14$ & 0.132 & 0.052 & 0.392 \\
H22/08 & Taurus & $\times$ & OP & 0.109 & 0.041 & 0.374 \\
H17/09 & First Gold & $\times$ & $03 / 12$ & 0.105 & 0.043 & 0.413 \\
H27/09 & Pioneer & $\times$ & OP & 0.022 & 0.213 \\
H27/07 & 5108 & $\times$ & $03 \mathrm{~N} 6 / 19$ & 0.088 & 0.035 & 0.401 \\
H6/08 & Taurus & $\times$ & $06 / 1$ & 0.079 & 0.028 & 0.352 \\
H24/09 & First Gold & $\times$ & OP & 0.079 & 0.029 & 0.363 \\
H6/09 & Agnus & $\times$ & $07 / 12$ & 0.079 & 0.019 & 0.237 \\
H4/09 & 4849 & $\times$ & $07 / 12$ & 0.072 & 0.025 & 0.347 \\
H11/09 & Admiral & $\times$ & $00 / 13$ & 0.067 & 0.023 & 0.342 \\
H10/09 & Taurus & $\times$ & $00 / 13$ & 0.057 & 0.021 & 0.362 \\
\hline
\end{tabular}


$\mathrm{T}$ a $\mathrm{b} 1$ e 3

Chemical analyses of hop genotypes with high DMX contents

\begin{tabular}{|l|c|c|c|c|c|c|}
\hline Genotype & Origin & $\begin{array}{c}\text { Alpha acids } \\
{[\% \mathrm{w} / \mathrm{w}]}\end{array}$ & $\begin{array}{c}\text { Beta acids } \\
{[\% \mathrm{w} / \mathrm{w}]}\end{array}$ & $\begin{array}{c}\text { Cohumulone } \\
{[\% \mathrm{rel} .]}\end{array}$ & $\begin{array}{c}\text { Xanthohumol } \\
{[\% \mathrm{w} / \mathrm{w}]}\end{array}$ & $\begin{array}{c}\text { DMX } \\
{[\% \mathrm{w} / \mathrm{w}]}\end{array}$ \\
\hline BM 14 & Czech & 13.8 & 8.2 & 32.8 & 0.79 & 0.46 \\
BM 28 & Czech & 9.9 & 7.0 & 27.1 & 0.46 & 0.37 \\
Vital & Czech & 14.5 & 8.1 & 22.4 & 0.60 & 0.29 \\
BM 03 & Czech & 10.8 & 3.5 & 27.5 & 0.48 & 0.27 \\
Sladek & Czech & 6.9 & 6.3 & 25.4 & 0.79 & 0.18 \\
Dunav & Yugoslavian & 7.8 & 4.8 & 26.1 & 0.34 & 0.18 \\
Smena & Russian & 6.3 & 5.0 & 25.1 & 0.38 & 0.16 \\
Cascade & US & 5.0 & 7.9 & 32.4 & 0.45 & 0.16 \\
Pioneer & English & 10.1 & 3.9 & 33.1 & 0.44 & 0.15 \\
Atlas & Slovenian & 8.0 & 4.2 & 39.3 & 0.42 & 0.15 \\
Agnus & Czech & 12.1 & 6.4 & 34.1 & 0.92 & 0.15 \\
\hline
\end{tabular}

$\mathrm{T}$ a b 1 e 4

Influence of the locality on DMX contents

\begin{tabular}{|l|c|c|c|c|}
\hline \multirow{2}{*}{ Locality } & \multicolumn{3}{|c|}{ DMX contents [\% w/w] } \\
\cline { 2 - 5 } & 2007 & 2008 & 2009 & Average \\
\hline Mradice & 0.31 & 0.29 & 0.35 & 0.32 \\
Mukoděly & 0.38 & 0.34 & 0.35 & 0.36 \\
Kněževes & 0.30 & 0.34 & 0.25 & 0.30 \\
Stekník I. & 0.29 & 0.26 & 0.22 & 0.33 \\
Očihov & 0.37 & 0.26 & 0.36 & 0.28 \\
Rybňany & 0.32 & 0.27 & 0.25 & 0.29 \\
Stekník II. & 0.32 & 0.28 & 0.28 & 0.30 \\
Average (\% w/w) & 0.33 & 0.29 & 0.29 & \\
\hline
\end{tabular}

dustry and therefore we registered it under the name of Vital. We plan to utilize this cultivar in pharmaceutical industry.

Vital is the first Czech hop cultivar suitable for pharmaceutical purposes. It showed very high content of pharmaceutically needed ingredient - DMX $(0.3-0.4 \% \mathrm{w} / \mathrm{w}$.). This content was two to three times higher than in all other hop cultivars grown all over the world (Nesvadba \& Krofta 2009). DMX isomerizes to 8-prenylnaringenin, which is known for its anti-carcinogenic effect (Biendl 2002). This is the reason why we chose the name Vital for this new hop cultivar. Vital belongs to the group of high-alpha hops if we take into consideration the division of hop cultivars from the brewing point of view (13-17\% content of alpha acids). There were even some localities where Vital commonly reached the content higher than $17 \%$. It was also known for its high beta acids content (7-10\%). 
Vital was bred by selection from the progeny of hybrid material. Agnus had the highest share in its origin.

Vital is typical for its green bine, higher bearing of fertile laterals and high weight of hop cones of regular cylindrical shape. It is a late cultivar and very easy to pick. We carried out pilot trials, where we intended to test other characteristics of this cultivar. The influence of locality on DMX contents was shown in Table 4. It was evident that Vital showed average content of DMX at the level of $0.31 \%$ (in the range of $0.27-0.38 \%$ ). The locality Mukoděly was typical for very high alpha acid content as well as high content of DMX. Apparently, this locality had very positive influence on DMX content. On the contrary, the lowest DMX content was found out in the field determined for maintenance breeding at the farm in Stekník. It was clear that not only the locality but also a year had considerable influence on DMX contents. The year 2007 brought higher average content of DMX $(0.33 \%)$ than the following years 2008 and $2009(0.29 \%)$.

\section{CONCLUSIONS}

Progenies obtained after crossing parents with high DMX contents show high variability of this feature. Very few genotypes show needed contents of DMX $(>0.25 \%)$. The partial results point out that DMX content is probably based on the action of more genes. It means that it will be difficult to obtain new genotypes with high DMX contents, which is furthermore influenced by a locality. The cultivar Vital has $0.27 \%$ average content of DMX in a nursery. In certain conditions this new perspective genotype has DMX content as high as $0.46 \%$. Therefore, we can conclude that we have succeeded in obtaining new hop genotypes suitable for pharmaceutical industry.

Acknowledgement. Czech Ministry of Education supported this work within the Research Project no.
2B06011: "The Development of Hop Genotypes for Biomedical and Pharmaceutical Purposes."

\section{REFERENCES}

BIENDL, M. 2002. The contents of xanthohumol and 8-prenylnaringenin in hop cones and hop products. In Hmeljarski bilten, vol. 9, 2002, pp. 27-34.

DE KEUKELEIRE, J. - OOMS, G. - HEYERICK, A. - VAN BOCKSTAELE, E. 2003. Formation and accumulation of alpha acids, beta acids, desmethylxanthohumol and xanthohumol during flowering of hops (Humulus lupulus L.). In Journal of Agricicultural and Food Chemistry, vol. 51, 2003, pp. 4436-4441.

KROFTA, K. - NESVADBA, V. 2008. The contents of xanthohumol and desmethylxanthohumol in genetic sources of hop (Humulus Lupulus L.). In Use Genetic Resources of Cultivated Plants : Proceedings of the International Scientific Meeting, Czech Republic, Saaz. Žatec: Chmelařský institut, 2008. ISBN 978-80-86836-33-1, pp. 19-23.

MIRANDA, C.L. - APONSO, G.L.M. - STEVENS, J.F. - DEINZER, M.L. - BUCHLER, D.R. 2000. Prenylated chalcones and flavanones as inducers of quinone reductase in mouse Hepa 1c1c7 cells. In Cancer Letters, vol. 149, 2000, no. 1-2, pp. 21-29.

NESVADBA, V. - KROFTA, K. 2003. Practical knowledge and criteria influencing effectivity of breeding process in the CR. In Proceedings of the Scientific Commission. Dobrna-Žalec, Slovenia, June 2003. ISSN 1814-2206, pp. 101-105.

NESVADBA, V. 2007. Vliv obsahu a složeni chmelových pryskyřic na obsah xanthohumolu a desmethyxanthohumolu $u$ chmele (Humulus lupulus L.) [Influence of the content and structure of hop resins on xanthohumol and desmethylxanthohumol (DMX) contents in hops (Humulus lupulus L.)]. In Proceedings of Czech Hop Growers Convention, Prague. Hop Research Institute: Zatec , 2007. ISBN: 97880-86836-09-6, pp. 12-18.

NESVADBA, V. - KROFTA, K. 2009. Variability in the contents of important compounds for pharmaceutical and brewing industries within hop gene fond. In Agriculture (Pol'nohospodárstvo), vol. 55, 2009, no. 1, pp. 10-16.

TOBE, H. - MURAKI, Y. - KITAMURA, K. - KOMIYAMA, O. - SATO, Y. - SUGIOKA, T. - MARUYAMA, H.B. MATSUDA, E. - NAGAI, M. 1997. Bone resorption inhibitors from hop extract. In Bioscience Biotechnology Biochemistry, vol. 61, 1997, no. 1, pp. 158-159.

Received: August, $5^{\text {th }}, 2009$ 